Vol. 7 (9), pp. 255-262, November 2017

ISSN: 2276-7770; ICV: 6.15

Copyright (C2017, the copyright of this article is retained by the author(s)

DOI: http://doi.org/10.15580/GJAS.2017.9.110917164

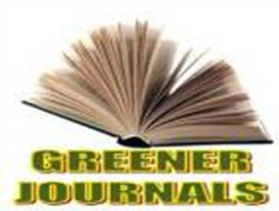

http://gjournals.org/GJAS

\title{
Response of Applied Phosphorus Fertilizer Rate and Plant Spacing for Potato (Solanum tuberosum L.) Production on Nitisols in Central Highland of Ethiopia
}

\section{Girma Chala* ${ }^{\star 1}$, Abebe Chindi ${ }^{2}$ and Zeleke Obsa ${ }^{2}$}

\author{
${ }^{1,2}$ Holeta Agriculture Research Centre, EIAR, P.O.Box 31, Holeta, Ethiopia
}

Article No.: 110917164

Type: Research

DOI: 10.15580/GJAS.2017.9.110917164

Submitted: 09/11/2017

Accepted: 22/11/2017

Published: $30 / 11 / 2017$

${ }^{*}$ Corresponding Author

Girma Chala

E-mail: chalagirma4@gmail.com

Keywords:

phosphorus fertilizer, plant spacing, potato
The use of low phosphorus fertilize rate as well as inappropriate plant spacing are one of the main factors constraining potato production in Ethiopia. Therefore, a field experiment was conducted during the 2015 and 2016 main growing season in Welmera and Ada'a Berga district in the central highland of Ethiopia. The experiment was aimed at determining the effect of phosphorus fertilizer rates and plant spacing on yield and yield components of potato. The treatments consisted of five phosphorus fertilizer rate and four levels of plant spacing $(65 \mathrm{~cm} \times 30 \mathrm{~cm}$, $75 \mathrm{~cm} \times 30 \mathrm{~cm}, 85 \mathrm{~cm} \times 30 \mathrm{~cm}$ and $95 \mathrm{~cm} \times 30 \mathrm{~cm}$ ). The experiment was laid out as a randomized complete block design in a factorial arrangement and replicated three times. Analysis of the results revealed that phosphorus fertilizer and plant spacing significantly affected leaf area index, marketable tuber number, total tuber numbers, total yields, specific gravity and tuber dry matter. However, days to follower and days to maturity significantly affected by phosphorus fertilizer but did not affect by plant spacing. Increasing or widening plant spacing significantly reduced total as well as unmarketable tuber yields whereas decreasing or narrowing it significantly increased this yield parameter. On the other hand, increasing plant spacing significantly increased marketable tuber yields. In conclusion, the phosphorus fertilizer and plant spacing produced the highest tuber yields (ton $\mathrm{ha}^{-1}$ ) as well as marketable tuber yield in response to planting at phosphorus fertilizer in the form of $\mathrm{P}_{2} \mathrm{O}_{5} 115 \mathrm{~kg} \mathrm{ha}^{-1}$ and spacing of $85 \mathrm{~cm}$ between rows and $30 \mathrm{~cm}$ between plants for Belete variety was advisably. 


\section{INTRODUCTION}

Potato (Solanum tuberosum L.) is an important food and cash crop in eastern and central Africa, playing a major role in national food security and nutrition, poverty alleviation and income generation, and provides employment in the production, processing and marketing sub-sectors (Lung'aho et al., 2007).In its efforts to transform the economy of the country, the Ethiopian government has planned a five-year rapid agricultural growth programme (AGP) (FDRE,2011), which considers potato as a strategic crop. With increasing urbanization, the potato is not only being used as a fresh tuber but also in processed products such as French fries and crisps (Abebe et al., 2013; Haverkort et al., 2012).

Ethiopia is endowed with suitable climatic and edaphic conditions for quality potato production. About $70 \%$ of the available agricultural land is located at an altitude of 1800-2500 metres above sea level and receives an annual rainfall of more than $600 \mathrm{~mm}$, which is suitable for potato production (Solomon, 1985). Potato has now become an important food and cash crop in Ethiopia, especially in the high and mid altitude areas

The crop is currently being grown by approximately 1 million farmers (ECSA, 2008/2009). The total area cropped with potato increased significantly from 40,000 hectares in 1996 to 160,000 in 2006 . However, given the available potential, the area used for potato production in the country is still very small. The average yield is very low (Gildemacher et al., 2009), which is far below the potential. The low acreage and yield of potato in Ethiopia are attributed to many factors. The major ones are lack of well adapted and highyielding cultivars, unavailability and high cost of seed tubers, inappropriate agronomic practices, low soil fertility and lack of marketing and suitable post-harvest management facilities, pests and disease (Gildemacher et al., 2009).

The most common recommended spacing for ware potato production in Ethiopia is $75 \mathrm{~cm}$ between rows and $30 \mathrm{~cm}$ between plants. On the other hand, the spacing for seed potato production should be usually smaller, about $65 \mathrm{~cm}$ between rows and $30 \mathrm{~cm}$ between plants (Lung'aho et al., 2007). However, the same spacing is commonly used for both ware and seed potato production of different potato varieties despite their distinct growth morphology in many areas of the country. However, plant spacing should depend on type of variety, fertility status of soil, plant architecture or growth habit etc. Therefore, using the same spacing for all varieties may not lead to optimum tuber yields. (Lung'aho et al., 2007).

Seed tubers that are plant too deep will be slow to emerge and may be more subject to attack by various diseases. Very shallow planting of seed tubers may result in inadequate soil moisture around the seed piece and in production of tubers so close to the soil surface that greening caused by exposure to light is more of a problem. Planting should be deeper on lighter soils than on heavy ones and deeper late in the season than early. Many growers like to plant seed tubers relatively deep but cover them with only a shallow layer of soil. More soil covering will then be added as the plant develops. A good rule of thumb is never to have more than $10 \mathrm{~cm}$ of soil above the tip of the developing sprout (Ngungi, 1982).

On the other hand, potato, because of its shallow root system and higher photosynthetic assimilation and dry matter accumulation for tuber yields, requires large amounts of nutrients (perrenoud, 1983; Dechassa et al., 2003). The crop absorbs large quantities of plant nutrients, especially nitrogen $(N)$, phosphorus $(\mathrm{P})$ and potassium $(\mathrm{K})$ from the soil (White et al., 2009). The rate of nitrogen fertilizer is a key consideration in managing fertility, because excessive applications in managing, because excessive applications delay maturity and reduce the partitioning of dry matter to the tubers, not to mention possible adverse effects on processing quality and on the environment (Ewing,1997). Soil should be ridged up along the potato row to provide extra cover for the developing tubers. This tends to reduce the number of tubers that stick out of the soil and are exposed to light. Even diffuse light filtering down through the cracks in the soil will cause tubers that turn green in the field are called sun burned and are unfit for consumption. Second benefits of ridging up the soil are that it facilitates harvest and provides weed control (Thompson and Kelly, 1983).

In the study area, information for potato production fertilizer rate, plant spacing and other agronomic practices is limited for optimum tuber yield. Hence, determining optimum phosphorus fertilizer and planting spacing for potato production is very important to come up with relevant recommendations that can optimize potato tuber yield.Therefore, this study was conducted to determine the response of phosphorus rate supply and plant spacing on yield and yield components of potato under nitisols in central highlands of Ethiopia.

\section{MATERIALS AND METHODS}

\subsection{Description of the Study Area}

The field experiment was conducted in Welmera and Ada'a Barga district, which is located in West Shewa Zone of Oromia Regional State in Ethiopia. The district is situated at the distance of $29 \mathrm{~kg}$ and $64 \mathrm{~km}$ West and North West of Addis Ababa with altitudes ranging between 2400 and 2800 metres above sea level, respectively.

The study area receives about $1184 \mathrm{~mm}$ mean annual rainfall. The rainy season extends from May to October and the maximum rain is received in the months of June to August. The mean annual temperature is about $17.5^{\circ} \mathrm{C}$, with the mean maximum and minimum temperatures of $25^{\circ} \mathrm{C}$ and $10^{\circ} \mathrm{C}$, respectively. The soil of 
the area is characteristically Nitosol, which is reddish brown in colour and clay loam in texture and its $\mathrm{pH}_{\mathrm{H}}$ range 4.2 to 6.4 .

\subsection{Experimental Materials}

The experiment was conducted using five phosphorus rate and four type of plant spacing. The farmer's used for potato production in the study area for a long period of time used $65 \mathrm{~cm} \times 30 \mathrm{~cm}$ and $75 \mathrm{~cm} \times 30 \mathrm{~cm}$ between row and plant spacing. Seed tubers used Belete variety was released 2009 from Holeta Agricultural Research Centre and stored for three months in diffused light store (DLS) along with the two varieties until sprouting and planting.

\subsection{Treatments and Experimental Design}

The treatments consisted of five phosphorus rate $(0,69$, 92,115 and $\left.138 \mathrm{~kg} \mathrm{P}_{2} \mathrm{O}_{5} \mathrm{ha}^{-1}\right)$ and four type of plant spacing $(65 \mathrm{~cm} \times 30 \mathrm{~cm}, 75 \mathrm{~cm} \times 30 \mathrm{~cm}, 85 \mathrm{~cm} \times 30 \mathrm{~cm}$ and $95 \mathrm{~cm} \times 30 \mathrm{~cm})$, respectively. The experiment was laid out as a randomized complete block design (RCBD) in a factorial arrangement and replicated three times. The gross plot size was $3 \mathrm{~m} \times 3 \mathrm{~m}\left(9 \mathrm{~m}^{2}\right)$ accommodating a minimum of 20 harvestable plants with different rows and space lengths. The net plot size was determined with area and plant density leaving the two outermost rows and sides of each row.

\subsection{Experimental Procedures}

Land preparation was done at the end of April accordance with a standard practice locally used. The experimental plot was cultivated by an oxen-drawn implement to the depth of $25-30 \mathrm{~cm}$. The land was levelled and ridges were made manually. Sprouted medium sized seed tubers (with a sprout length of 1.5 to $2.5 \mathrm{~cm}$ ) were planted at the end of May according to the specified treatments. Cultivation, weeding, chemical spray and harvesting were done at the appropriate time according to the research recommendations.

Application of phosphorus fertilizer at different rate of $\mathrm{P}_{2} \mathrm{O}_{5}$ ha $^{-1}$ were done by banding the granules of DAP (Di-ammonium phosphate) at the depth of $10 \mathrm{~cm}$ below and around the seed tuber at planting. Nitrogen at the rate of $75 \mathrm{~kg} \mathrm{~N}^{-1}$ was applied in the form of urea in three splits $\left[\left(1 / 3^{\text {rd }}\right.\right.$ at planting, $1 / 3^{\text {rd }}$ at mid-stage of (at about 45 days after planting), and $1 / 3^{\text {rd }}$ at the initiation of tubers (start of flowering)]. Harvesting was done at physiological maturity when the leaves of the potato plants senesced. Ten days before harvesting, the haulms of the potato plants were mowed using a sickle to toughen the periderm and pre-empt predisposal of tubers to skinning and bruising during harvesting.

\subsection{Data Collection and Measurements}

Days to flowering: was recorded as number of days from emergence to the time when 50 percent of the plant population in each plot produced flowers.

Plant height (cm): was measured by taking five randomly reselected plants per plot as the distance in $\mathrm{cm}$ from the soil surface to the top most growth point of aboveground at full maturity.

Leaf number per plant: was determined by counting leaf number from five plants (hills) taken at random in each plot before the start of tuber formation.

Leaf area index: To determine leaf area, five plants (hills) from each plot was randomly taken at 50 percent flowering. Then three sample leaves were measured using square peppers from each plant. By multiplying the average leaf area with the respective leaf number of the plant, total leaf area was calculated. LAI was calculated by dividing total leaf area to the respective land area occupied by plants.

Stem number: was recorded as average stem count of five hills per unit area at $50 \%$ flowering.

Days to maturity: Number of days from emergence to maturity was recorded when $95 \%$ percent of the plants of different treatments were ready for harvest as indicated by the senescence of the haulms.

Average tuber mass (g): This was obtained by dividing weight of tubers per plant by the number of tubers.

Marketable and unmarketable tuber numbers: Numbers of tubers were counted as marketable and unmarketable based on their size category. Tubers weighing greater than $25 \mathrm{~g}$ with no damages or blemishes were considered marketable.

Total tuber number: This was counted as the sum of marketable and unmarketable tubers from the net plot.

Marketable tuber yield (tons/ha): included marketable and healthy tubers with size categories greater than 25 g.

Unmarketable tuber yield (tons/ha): unmarketable tubers included unhealthy tubers as well as healthy tuber weighing d less than $25 \mathrm{~g}$.

Total tuber yield (tons/ha): total tuber yield was recorded as the sum of all marketable and unmarketable tubers.

Specific gravity of tubers $\left(\mathrm{gcm}^{-3}\right)$ : To determine the specific gravity, tubers of all size categories weighing about two kilogram's were randomly taken from each plot, washed with water. The sample was then first weighed in air and then re-weighed suspended in water. 
Specific gravity was then determined using the following formula (Kleinkopf et al, 1987).

Specific Gravity $=\quad \frac{\text { Weight in air }}{\text { Weight in air }- \text { Weight in water }}$

Tuber dry matter content (\%): Five fresh tubers were randomly selected from each plot and weighed at harvest. The tubers were then sliced and dried in an oven at $65^{\circ} \mathrm{C}$ for about $72 \mathrm{hrs}$ until a constant weight is obtained. The dry weight was recorded and the dry matter percent calculated according to Williams (1968).

Dry matter $(\%)=\frac{\text { Weight of sample after drying }(\mathrm{g})}{\text { Initial }} \times 100 \%$ Initial weight of sample $(\mathrm{g})$

\subsection{Statistical Analysis}

Analysis of variance (ANOVA) was done for Randomized Complete Block Design in a factorial arrangement using the Generalized Linear Model of the SAS procedure of version 9.1 (SAS, 2007). All significant pairs of treatment means were compared using the Least Significant Difference Test (LSD) at 5\% level of significance. Linear correlation analysis was done to know the association of traits.

\section{RESULT AND DISCUSSION}

\subsection{Growth Parameters}

The analysis of variance revealed that the treatments significantly affected days to flower, plant height, stem numbers, days to maturity, and leaf number per plant and leaf area index. The maximum plant height, stem number, leaf number per plant and leaf area index was observed at $115 \mathrm{~kg} \mathrm{ha}^{-1}$ phosphorus rate (Table 1). While, the highest number of days to flowering and days to maturate was recorded at zero rate of phosphorus (Table 1).

Plant height increased significantly in response to increasing or widening plant spacing. Thus, increasing plant spacing from $65 \mathrm{~cm} \times 30 \mathrm{~cm}$ to $95 \mathrm{~cm} \times 30$ resulted in significant increases in plant height by about $32 \%$. Similarly, stem number, leaf number per plant and leaf area index also increasing as plant spacing increased from $65 \mathrm{~cm} \times 30 \mathrm{~cm}$ to $95 \mathrm{~cm} \times 30$ but days to flowering and maturity non significance observed among the treatments (Table1).The increased plant height, stem number, leaf number per plant and leaf area index in response to increasing plant spacing may be attributed to the fact that relatively more spacing may lead to less competition among plants for growth factors such as nutrients, moisture, and light leading to enhanced vegetative growth and increased plant height. This shows that plant growth parameters are influenced by environmental factors. This suggestion is corroborated by that of Singh and Singh (1973) who reported that environmental factors like nutrient status of the soil, available moisture and intercepted radiation significantly influence plant growth.

Table 1: Effect of phosphorus and plant spacing on potato growths parameters.

\begin{tabular}{|c|c|c|c|c|c|c|}
\hline Treatments & DF & $\mathrm{PH}$ & SN & DPM & LNP $^{-1}$ & LAI \\
\hline \multicolumn{7}{|c|}{ Phosphorus(kg/ha) } \\
\hline 0 & $84.38^{\mathrm{a}}$ & $63.86^{\mathrm{C}}$ & $18.6^{\mathrm{c}}$ & $116.5^{\mathrm{a}}$ & $589.6^{c}$ & $3.2^{\mathrm{c}}$ \\
\hline 69 & $74.7^{\mathrm{b}}$ & $76.37^{b}$ & $24.9^{b}$ & $110.62^{a b}$ & $681.0^{\mathrm{bc}}$ & $4.02^{b}$ \\
\hline 92 & $70.2^{\mathrm{b}}$ & $82.28^{\mathrm{b}}$ & $29.3^{\text {ab }}$ & $106.89^{\mathrm{b}}$ & $711.6^{\mathrm{b}}$ & $4.6^{\mathrm{b}}$ \\
\hline 115 & $64.6^{\mathrm{c}}$ & $96.64^{\mathrm{a}}$ & $32.24^{\mathrm{a}}$ & $103.14^{\mathrm{bc}}$ & $784.04^{\mathrm{a}}$ & $4.88^{a}$ \\
\hline 138 & $62.8^{c}$ & $94.87^{\mathrm{a}}$ & $32.03^{a}$ & $102.02^{c}$ & $776.9^{\mathrm{ab}}$ & $4.84^{\mathrm{a}}$ \\
\hline LSD (0.05 ) & 3.68 & 4.86 & 2.82 & 2.74 & 18.63 & 0.69 \\
\hline \multicolumn{7}{|l|}{ Plant Spacing } \\
\hline $65 \mathrm{~cm} \times 30 \mathrm{~cm}$ & 81.00 & $74.12^{c}$ & $22.8^{\mathrm{b}}$ & 110.02 & $566.29^{c}$ & $3.8^{\mathrm{c}}$ \\
\hline $75 \mathrm{~cm} \times 30 \mathrm{~cm}$ & 78.24 & $82.28^{\mathrm{b}}$ & $24.5^{\mathrm{ab}}$ & 108.0 & $623.6^{\mathrm{b}}$ & $4.13^{\mathrm{b}}$ \\
\hline $85 \mathrm{~cm} \times 30 \mathrm{~cm}$ & 80.22 & $92.16^{\mathrm{ab}}$ & $27.3^{\mathrm{a}}$ & 110.61 & $756.2^{a}$ & $4.64^{\mathrm{a}}$ \\
\hline $95 \mathrm{~cm} \times 30 \mathrm{~cm}$ & 84.16 & $97.62^{\mathrm{a}}$ & $28.8^{a}$ & 112.16 & $781.7^{\mathrm{a}}$ & $4.58^{\mathrm{a}}$ \\
\hline LSD (0.05) & NS & 3.15 & 1.44 & NS & 4.38 & 0.88 \\
\hline CV (\%) & 4.34 & 5.68 & 4.06 & 1.84 & 8.12 & 16.2 \\
\hline
\end{tabular}

Means followed by the same letter within a column are not significantly different at $5 \%$ level of significance $L S D=$ Least significant differences; $C V=$ coefficient of variation; $P H=$ plant height; $D F=$ days to $50 \%$ flowering; $D P M=$ days to $50 \%$ maturity; $S N=$ main stem number; $L N P^{-1}=$ Leaf number per plant; $L A I=L$ eaf area index.

\subsection{Yield Components}

The analysis of variance showed that total tuber number, marketable tuber number, unmarketable tuber number 
and average tuber weight produced per $\mathrm{m}^{2}$ were significantly $(P<0.01)$ influenced by the phosphorus rate, as well as plant spacing. As the results indicated from (Table 2) as phosphorus rate increasing total tuber number, marketable tuber number and average tuber weight were highly increased except unmarketable tuber numbers, this is due to potato high responsive when compared to other tuber crops. The increase in average tuber number might be due to the increased photosynthetic activity and translocation of photosynthetic to the root, which might have helped in the initiation of more stolen in potato as reported by Annad and Krishinapp (1989).

The results indicate that planting at the narrower spacing resulted in the production of higher numbers of total as well as unmarketable tubers than planting at the wider spacing. On the other hand, planting at the wider spacing resulted in the production of higher numbers of marketable tubers (Table 2). This may be attributed to the fact that narrower planting may result in the production of large numbers of stems per unit area, which may lead to stiff competition among plants and tubers for growth factors, rendering the tubers smallsized and underdeveloped. However, wider spacing may result in the production of smaller number of stems per unit area, thereby lessening the competition for growth factors among plants and tubers and leading to the production of large-sized tubers. This suggestion is in accordance with that of Lung'aho et al. (2007) who described that narrower spacing resulted in the production of many stems with in many small-sized tubers whereas wider spacing results in the production of a fewer stems per unit area resulting in the production of fewer large-sized tubers.

\section{Table 2: Effects of phosphorus and plant spacing on total, marketable and unmarketable tuber number per $\mathrm{m}^{2}$, average tuber weight, and average tuber number per plant

\begin{tabular}{|c|c|c|c|c|}
\hline Treatments & $\begin{array}{l}\text { Total tuber } \\
\text { number per } \mathrm{m}^{2}\end{array}$ & $\begin{array}{l}\text { Marketable tuber } \\
\text { number per } \mathrm{m}^{2}\end{array}$ & $\begin{array}{l}\text { Unmarketable } \\
\text { tuber number } \\
\text { per } \mathrm{m}^{2}\end{array}$ & $\begin{array}{l}\text { Average tuber } \\
\text { weight(g) }\end{array}$ \\
\hline
\end{tabular}

\begin{tabular}{lllll}
\hline $\begin{array}{l}\text { Phosphorus(kg/ha } \\
\text { ) }\end{array}$ & & & \\
0 & $58.5^{\mathrm{cd}}$ & $27.72^{\mathrm{d}}$ & $30.78 \mathrm{a}$ & $812.84^{\mathrm{a}}$ \\
69 & $66.68^{\mathrm{c}}$ & $41.4^{\mathrm{c}}$ & $25.28 \mathrm{ab}$ & $1658.6^{\mathrm{c}}$ \\
92 & $79.8^{\mathrm{b}}$ & $69.6^{\mathrm{b}}$ & $10.2 \mathrm{c}$ & $2582.8^{\mathrm{b}}$ \\
115 & $87.24^{\mathrm{a}}$ & $81.22^{\mathrm{a}}$ & $6.02 \mathrm{~cd}$ & $4268.4^{\mathrm{a}}$ \\
\hline 138 & $82.65^{\mathrm{ab}}$ & $78.62^{\mathrm{ab}}$ & $4.03 \mathrm{~d}$ & $4167.5^{\mathrm{a}}$ \\
\hline LSD (0.05) & 4.64 & 6.82 & 2.87 & 6.84 \\
\hline Plant Spacing & & & & \\
$65 \mathrm{~cm} \times 30 \mathrm{~cm}$ & $96.7^{\mathrm{a}}$ & $42.3^{\mathrm{c}}$ & $54.4 \mathrm{a}$ & $2273.5^{\mathrm{a}}$ \\
$75 \mathrm{~cm} \times 30 \mathrm{~cm}$ & $79.1^{\mathrm{b}}$ & $60.4^{\mathrm{b}}$ & $18.7 \mathrm{~b}$ & $2872.2^{\mathrm{c}}$ \\
$85 \mathrm{~cm} \times 30 \mathrm{~cm}$ & $81.7^{\mathrm{c}}$ & $68.4^{\mathrm{a}}$ & $13.3 \mathrm{c}$ & $4171.7^{\mathrm{a}}$ \\
$95 \mathrm{~cm} \times 30 \mathrm{~cm}$ & $72.9^{\mathrm{d}}$ & $64.2^{\mathrm{a}}$ & $8.7 \mathrm{~cd}$ & $4072.8^{\mathrm{a}}$ \\
LSD (0.05) & 4.36 & 4.29 & 1.1 & 2.36 \\
\hline CV (\%) & 7.24 & 8.05 & 11.3 & 15.27 \\
\hline
\end{tabular}

Means followed by the same letter with in a column are not significantly different at $5 \%$ level CV = Coefficient variation; $L S D=$ Least significant differences

The analysis of variance revealed that the treatments significantly affected total tuber yield, marketable tuber yield and unmarketable tuber yield was significantly $(\mathrm{P}<$ 0.01 ) influenced by the phosphorus rate, as well as plant spacing. The maximum total tuber yield and marketable tuber yield was observed at $115 \mathrm{~kg} \mathrm{ha}^{-1}$ phosphorus rate, but the highest unmarketable tuber yield was recorded at zero rate of phosphorus (Table 3 ).

The result showed that widening plant spacing significantly increased total tuber yield and marketable tuber yield but decreased unmarketable tuber yield. Thus, plants grown at the wider plant spacing produced significantly higher total tuber yield and marketable tuber yields than plants grown at the narrower spacing (Table 3). Thus, for example, the marketable tuber yields of plants cultivated at the spacing of $85 \mathrm{~cm}$ between rows and $30 \mathrm{~cm}$ between plants exceeded the total tuber yield and marketable tuber yields of plants grown at the spacing of $65 \mathrm{~cm}$ between rows and $30 \mathrm{~cm}$ between plants by additional percentage of about 14 and $26 \%$, respectively. The production of higher total and marketable tuber yield in response to planting the seed tubers at wider or increased spacing may be attributed low competition between plants for growth factors such as moisture, nutrients, and light and the optimal utilization of the growth factors for photosynthesis and assimilation of carbohydrates to tubers. This finding is in agreement with that of Wurr (1992) who reported that narrower spacing led to the production of many smallsized tubers that were not marketable. 
Table 3: Effects of phosphorus and plant spacing on total, marketable, and unmarketable tuber yield (ton ha ${ }^{-1}$ ) of potato

\begin{tabular}{llll}
\hline Treatments & $\begin{array}{l}\text { Total tuber yield(ton } \\
\text { ha }^{-1} \text { ) }\end{array}$ & $\begin{array}{l}\text { Marketable tuber } \\
\text { ha }^{-1} \text { ) }\end{array}$ & $\begin{array}{l}\text { Yield(ton } \\
\text { (ton ha } \text { h }^{-1}\end{array}$ \\
\hline Phosphorus(kg/ha) & & & \\
0 & $18.6^{\mathrm{d}}$ & $9.64^{\mathrm{d}}$ & $8.96^{\mathrm{a}}$ \\
69 & $29.74^{\mathrm{c}}$ & $22.26^{\mathrm{c}}$ & $7.48^{\mathrm{b}}$ \\
92 & $32.43^{\mathrm{b}}$ & $28.18^{\mathrm{b}}$ & $4.25^{\mathrm{c}}$ \\
115 & $38.68 \mathrm{a}$ & $35.52^{\mathrm{a}}$ & $3.16^{\mathrm{cd}}$ \\
138 & $37.96 \mathrm{a}$ & $35.34^{\mathrm{a}}$ & $2.62^{\mathrm{d}}$ \\
LSD (0.05) & 9.786 & 7.83 & 1.13 \\
\hline Plant Spacing & & & \\
$65 \mathrm{~cm} \times 30 \mathrm{~cm}$ & $32.51^{\mathrm{b}}$ & $28.16^{\mathrm{c}}$ & $4.35^{\mathrm{a}}$ \\
$75 \mathrm{~cm} \times 30 \mathrm{~cm}$ & $35.13^{\mathrm{ab}}$ & $31.57^{\mathrm{b}}$ & $3.56^{\mathrm{b}}$ \\
$85 \mathrm{~cm} \times 30 \mathrm{~cm}$ & $37.14^{\mathrm{a}}$ & $35.36^{\mathrm{a}}$ & $1.78^{\mathrm{c}}$ \\
$95 \mathrm{~cm} \times 30 \mathrm{~cm}$ & $36.82^{\mathrm{a}}$ & $35.17^{\mathrm{a}}$ & $1.65^{\mathrm{cd}}$ \\
LSD (0.05) & 1.68 & 1.98 & 0.46 \\
\hline CV (\%) & 5.52 & 8.66 & 6.48
\end{tabular}

Means followed by the same letter within a column are not significantly different at $5 \%$ level of significance. $L S D=$ Least significant differences; $C V=$ coefficient variation.

\subsection{Some Quality Parameters}

The analysis of variance revealed that the treatments significantly affected specific gravity and tuber dry matter. As indicated from the results the highest specific gravity and tuber dry matter were observed at $138 \mathrm{~kg} \mathrm{ha}^{-1}$ phosphorus rates (Table 4). However, plants grown at the wider spacing of $85 \mathrm{~cm} \times 30 \mathrm{~cm}$ had 1.056 and 23.01 specific gravity and tuber dry matter was recorded. This implies that specific gravity is one of the most important traits in potato crop that may provide a faster and easier measure of dry matter content (Tai et al., 1985). This is consistent with the suggestion of Tekalign (2005) that the positive correlation between specific gravity and tuber dry matter content signifies that specific gravity is a true indicator of the amount of dry matter of tubers.

Table 4: Effects of phosphorus and plant spacing on some potato tuber quality parameters Treatments Specific gravity Tuber dry matter (\%)

\begin{tabular}{lll}
\hline Phosphorus(kg/ha) & & \\
0 & $1.002^{\mathrm{d}}$ & $21.8^{\mathrm{d}}$ \\
69 & $1.026^{\mathrm{c}}$ & $22.4^{\mathrm{c}}$ \\
92 & $1.048^{\mathrm{b}}$ & $22.8^{\mathrm{b}}$ \\
115 & $1.062^{\mathrm{ab}}$ & $23.08 \mathrm{a}$ \\
138 & $1.072^{\mathrm{a}}$ & $23.3 \mathrm{a}$ \\
LSD $(0.05)$ & 0.009 & 0.39 \\
\hline Plant Spacing & & \\
$65 \mathrm{~cm} \times 30 \mathrm{~cm}$ & $1.023^{\mathrm{c}}$ & $22.16^{\mathrm{bc}}$ \\
$75 \mathrm{~cm} \times 30 \mathrm{~cm}$ & $1.048^{\mathrm{b}}$ & $22.84^{\mathrm{ab}}$ \\
$85 \mathrm{~cm} \times 30 \mathrm{~cm}$ & $1.056^{\mathrm{a}}$ & $23.01^{\mathrm{a}}$ \\
$95 \mathrm{~cm} \times 30 \mathrm{~cm}$ & $1.055^{\mathrm{a}}$ & $23.0^{\mathrm{a}}$ \\
LSD (0.05) & 0.014 & 0.36 \\
\hline CV (\%) & 1.36 & 1.64 \\
\hline
\end{tabular}

Means followed by the same letter within a column are not significantly different at $5 \%$ level of significance. $L S D=$ Least significant differences; $C V=$ coefficient variation

\section{CONCLUSION}

The area in which this study was conducted is located in the central highland of the country and is one of the most densely populated regions with very small land holding per household. Potato is the main staple and food security crop next to cereal crops in the study area. Even though the study area is characterized as the potential potato producing area, using the low yielding due to use low fertilizer rate and local cultivars without standardized 
spacing led stallholder potato farmers to harvest low tuber yields. Interventions to increase agronomic practice and reduce NP losses to the environment must be accomplished at the farm level through a combination of improved technologies and carefully crafted local policies that promote the adoption of improved NP management practices while sustaining yield increases.

Increasing plant spacing significantly decreased the amount of unmarketable tuber yields produced. Thus, plants grown at the wider spacing produced lower unmarketable tuber yields. Thus, planting potato closely leads to the production of relatively higher proportion of unmarketable tubers as well as higher total tuber yields. On the other hand, decreasing plant spacing significantly increased the yield of very small-sized tubers but decreased yield of medium and large-sized tubers. The results of this study strongly imply that phosphorus fertilizer and spacing could be manipulated for higher yields of potatoes depending on the purpose of production i.e., whether for ware or seed potato. The results of the study also indicated that too much narrowing of plant spacing in potato production may lead to the production of large quantities of small-sized tubers that are too small to be marketed for both ware and seed purposes.

In conclusion, the results of this experiment revealed that cultivating high yield of Belete improved variety at the phosphorus fertilizer $115 \mathrm{~kg} / \mathrm{ha}$ in the form of $\mathrm{P}_{2} \mathrm{O}_{5}$ and plant spacing of $85 \mathrm{~cm}$ between rows and $30 \mathrm{~cm}$ between plants resulted in the highest total tuber and marketable tuber yield for Belete variety. Therefore, smallholder farmers in the study area, who often use the $115 \mathrm{~kg} \mathrm{P}_{2} \mathrm{O}_{5} \mathrm{ha}^{-1}$ and spacing of about $85 \mathrm{~cm}$ between rows and $30 \mathrm{~cm}$ between plants for the production of Belete variety, should be advised to revise their practice.

\section{ACKNOWLEDGEMENTS}

The authors also acknowledge the Ethiopian Institute of Agricultural Research (EIAR) and I would like to express my appreciation also to Mr. Tesfaye Negash, Mr. Haile Beza, Mr. Beyene Offa, Mrs. Kessach Birhanu, and Mrs. Tsige Kebede for their technical assistance during the execution of the experiments under field condition. Appreciation is also due for the services of the analytical soil laboratory of Holeta Agricultural Research Center of EIAR.

\section{REFERENCES}

Abebe, T., Lemaga, B., Mwakasendo, J A., Nzohabonayoz,Z., Mutware, J., Wanda, K.Y., Kinyae, P.M., Ortiz, O., Crissman, C., Thiele, G. 2010. Markets for fresh and frozen potato chips in the ASARCA region and the potential for regional trade: Ethiopia, Tanzania, Rwanda, Kenya, Burundi and Uganda. Working Paper. International Potato Centre (CIP). Lima, Peru, 44p.
Annad, S. and K. S. Krishnappa, 1989. Dry matter accumulation and nutrient uptake by potato cv.Kufri Badsha $\mathrm{h}$ as affected by deferent levels of $\mathrm{N}$ and $\mathrm{K}$ in sandy loam soil. Mysore Journal of Agricultural Sciences.23: $65-70$

Dechassa N., M. K. Schenk and N. Steingrobe. 2003. Phosphorus Efficiency of Cobbage (Brassica oleraceae L. var.capitata), Carrot, Carrot (Daucus carota L.), and Potato (Solanum tuberosum L.). Plant and Soil, 250: 215-224.

ECSA, 2009. (Ethiopia Central of Statistical Agency Anlaysis), Agricultural sample survey: Report on area and production of crops, Addis Abeba, Ethiopia. Pp. 126.

Ewing, E.E., 1997.Potato. In: H.C.Wien(ed). The physiology of vegetable crops. UK, Cambridge. Pp. 295-344.

FDRE (The Federal Democratic Republic of Ethiopia) 2011. Five Year Plan for Growth and Transformation (2011-2015). Addis Ababa, Ethiopia: Ministry of Finance and Economic Development.

Gildemacher, P.R., W. Kaguongo O. Ortiz Tesfaye Abebe, Gebremedhen Woldegiorgis. Wagoire,R.Kakuhenzire, P.M. Kinyae M.Nyongesa P.C. Struik and C. Leeuwis 2009. Improving potato production in Kenya,Uganda and Ethiopia: A System Diagnosis. Potato Research 52:173-205.

Haverkort, A.J., D. Uenk, H. Veroude and M. Vander Waart, 2012. Relationships between ground cover, intercepted solar radiation, leaf area index and infrared reflectance of potato crops. Potato Research. 34: 113-121

Kleinkopf,G. E., D. T.Wester mann and M. J. Willie, 1987. Specific gravity of Russet Burbank potatoes. American Potato Journal. 64: 579-587.

Lung'aho, C., B. Lemaga, M. Nyongesa, P. Gildermacher, P. Kinyale, P. Demo, and J. Kabira, 2007. Commercial seed potato production in eastern and central Africa. Kenya Agricultural Institute. 140p.

Ngungi, D.N., 1982. Agronomic concept of potato with reference to increasing the potential yield under tropical condition. In potato seed production for Tropical Africa, (ed.) Nganga, S. and shiderler, F. CIP, Lima. Peru. PP. 13-16.

Perrenoud S. 1983. Potato-Fertilizers for yield and quality. International Potash Institute, Bulletin No.8. Berne, Switzerland.84p.

Singh, T.P. and K.B. Singh, 1973. Association of grain yield and its components in segregations of green gram. Indian J. Genetics. 33: 112-117.

Solomon, Yilama, 1985. Review of potato research in Ethiopia. PP. 294 - 307. In: proceedings of $1^{\text {st }}$ Ethiopian Horticultural work shop. 20-22 February 1985, Addis Ababa, Ethiopia.

Tai, G. C., G. Misere, Alley and L. P. McMillan, 1985. GRAVA -O -TATER: A computer apparatus for measuring specific gravity. American Potato Journal. 62: 403-408. 
Tekalign, Tsegaw, 2005. Response of potato to paculobutrazol and manipulation of reproductive growth under tropical conditions. PhD thesis..PP 23.

Thompson, R. and W.J. Kelly, 1983. Vegetable crops. $5^{\text {th }}$ ed. MC Graw Hill Book Co. Inc., New York pp. 372-404.

White, P. J., Bradshaw, J.E., Finaly, M., Dale B. and Ramsay, G. 2009. Relationships between yield and mineral concentrations in potato tubers. Hort Science 44: 6-11.
William, M.A. and G.W. Woodbury, 1968. Specific gravity dry matter relationship and reducing sugar changes affected by potato variety, production area and storage. American Potato Journal. 45(4): 119131.

Wurr, D. C. E., 1992. Some effects of seed size and spacing on the yield and grading of two main crop potato varieties. Journal of Agricultural Sciences, Cambridge.82: 37-45.

Cite this Article: Girma C, Abebe C and Zeleke O (2017). Response of Applied Phosphorus Fertilizer Rate and Plant Spacing for Potato (Solanum tuberosum L.) Production on Nitisols in Central Highland of Ethiopia. Greener Journal of Agricultural Sciences, 7(9): 255-262, http://doi.org/10.15580/GJAS.2017.9.110917164. 